\section{Clinical Features of Pulmonary Lesions in Sickle-cell Anaemia}

\section{British Medical fournal, 1970, 3, 31}

Acute pulmonary diseases in patients with sickle-cell anaemia are usually diagnosed as pneumonia, but in our experience their rate of resolution and clinical course is different from pneumonia occurring in patients with normal haemoglobins. To confirm this we analysed the clinical course of these pulmonary episodes in a group of patients with sickle-cell anaemia and compared them with a control group of patients with acute lobar pneumonia.

\section{Patients and Methods}

Twenty-eight adult patients (8 male and 20 female) with sickle-cell anaemia were admitted to the University Hospital with a diagnosis of pneumonia during the period 1957-69. Age at admission varied from 11 to 55 years (mean 24.1 years). The diagnosis of sickle-cell anaemia was based on the finding of only haemoglobins $S, F$, and $A$ on electrophoresis, normal $A_{2}$ values, characteristic red cell morphology, and family studies where possible. Cases of sickle thalassaemia and $\mathrm{Hb}$ SC disease were excluded.

A control group of 28 patients (19 male and 9 female) with acute lobar pneumonia was selected from admissions to the medical wards. They were closely matched for age to the sickle-cell group and varied from 11 to 48 years of age (mean 23.3 years). The haematological data in the two groups are summarized in Table $I$.

\section{Clinical Features}

The symptoms and signs in the two groups are compared in Table II. The most striking differences were the tendency to recurrence and the duration of the pyrexia. In the sicklecell group the tendency to recurrence is shown by both a frequent previous history of pulmonary episodes and recurrent episodes during the same admission. In the control cases there was usually a dramatic resolution of pyrexia, and 23 cases were afebrile within 48 hours of admission, compared with 5 of the sickle-cell anaemia cases.

\section{Comment}

The clinical picture of the pulmonary episodes resembled acute lobar pneumonia in some of the sickle-cell patients,

TABLE II.-Symptoms and Signs in Both Groups of 28 Patients

\begin{tabular}{|c|c|c|c|c|}
\hline \multicolumn{3}{|c|}{ Feature } & $\begin{array}{l}\text { Sickle-cell } \\
\text { Anaemia }\end{array}$ & Control \\
\hline $\begin{array}{l}\text { Cough . . } \\
\text { Purulent sputum } \\
\text { Haemoptysis . } \\
\text { Previous history of puln } \\
\text { Pulmonary consolidatio } \\
\text { Pleural rub or effusion } \\
\text { Pathogen in sputum } \\
\text { Recurrent episodes in sa } \\
\text { Mean duration of fever }\end{array}$ & 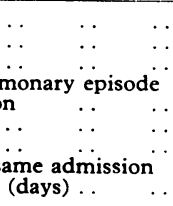 & $\begin{array}{ll}\cdots & \cdots \\
\cdots & \cdots \\
\cdots & \cdots \\
\cdots & \cdots \\
\cdots & \cdots \\
\cdots & \cdots \\
\cdots & \cdots\end{array}$ & $\begin{array}{r}20 \\
13 \\
1 \\
9 \\
27 \\
11 \\
3 \\
8 \\
81 \cdot 6(1-41)\end{array}$ & $\begin{array}{c}28 \\
22 \\
18 \\
0 \\
28 \\
4 \\
6 \\
0 \\
1 \cdot 9(1-5)\end{array}$ \\
\hline
\end{tabular}

but in others the general course led to a diagnosis of pulmonary infarction. It could be argued that if patients with sickle-cell anaemia develop pneumonia, the lower haemoglobin concentration and decreased oxygen delivery to the tissues delays resolution. But the decreased oxygen affinity of $\mathrm{Hb} \mathrm{S}$ and the increased cardiac output tend to improve the oxygen delivery capacity in these patients. An alternative explanation is that the inflammatory reaction and regional hypoxia occurring in pneumonia increases the formation of sickled cells, producing increased viscosity, stasis, and further ischaemia, thus complicating the resolution of the inflammatory process. Finally, it may be that most episodes are primarily infarction.

Evidence for the occurrence of pulmonary infarction in sickle-cell anaemia is substantial. The low mixed venous oxygen tensions present in the pulmonary artery and pulmonary capillary bed are compatible with widespread sickling in patients whose red cells contain high concentrations of $\mathrm{Hb} \mathrm{S}$. In these conditions in-vivo sickling can reach $30-60 \%$ of all red cells (Jensen, Rucknagel, and Taylor, 1960). The accompanying increase in blood viscosity (Greenberg, Kass, and Castle, 1957) and the rheological inefficiency of sickled cells are believed to predispose to vascular stasis, ischaemia, and infarction. The differential diagnosis of pneumonia from pulmonary infarction remains a difficult clinical problem. The promise of diagnostic assistance from biochemical and enzyme tests has not been fulfilled. Diggs and Barreras (1967) reviewed this problem in patients with sickle-cell anaemia. An interesting observation was the appearance of blister cells and poikilocytes in cases of pulmonary emboli, that disappeared as the lesion resolved (Barreras, Diggs, and Bell, 1968). The diagnostic value of these observations remains to be assessed.

In patients with recurrent episodes during the same admission there is usually a clear indication for anticoagulant therapy. The problem arises in the therapy of the single episode and there would be a case for a trial, giving both antibiotic and anticoagulant therapy on admission in these patients in an attempt to shorten the clinical course.

This work was supported by a grant from the Wellcome Trust, London. We wish to thank Dr. Paul Milner for the haematological investigations.

TABLE I.-Haematological Data in Both Groups of Patients

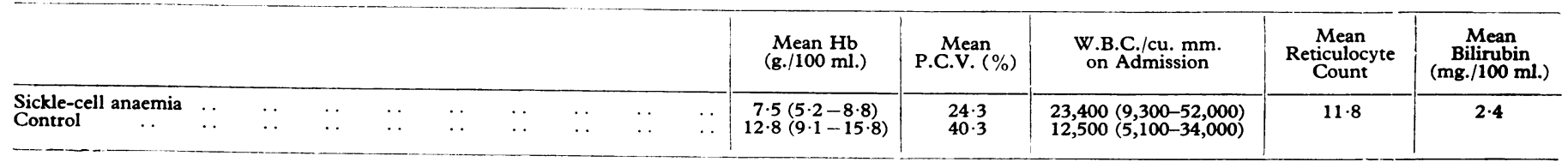

Michael C. Petch, M.B., M.R.C.P., Senior Registrar,

GRAHAM R. SERJEANT, M.B., M.R.C.P., Wellcome Research Fellow, Department of Medicine, University of the West Indies, Kingston, Jamaica.

\section{REFERENCES}

Barreras, L., Diggs, L. W., and Bell, A. (1968). Fournal of the American Medical Association, 203, 569.

Diggs, L. W., and Barreras, L. (1967). Memphis Medical fournal, 42 375 . Clinical Investigation, 36, 833 .
.

Jensen, W. N., Rucknagel, D. L., and Taylor, W. J. (1960). fournal of Laboratory and Clinical Medicine, 56, 854. 